\title{
Present status and future prospects of ornamental fishes at Chattogram region in Bangladesh
}

\author{
Uachash Barua $^{1}$, Sk. Ahmad-Al-Nahid ${ }^{2}$ \\ ${ }^{1}$ Department of Fisheries Resource Management, Chittagong Veterinary and Animal Sciences University, Chattogram-4225, \\ Bangladesh \\ ${ }^{2}$ Department of Fisheries Resource Management, Chittagong Veterinary and Animal Sciences University, Chattogram-4225, \\ Bangladesh \\ Corresponding Author: \\ Uachash Barua, Department of Fisheries Resource Management, Chittagong Veterinary and Animal Sciences University, \\ Chattogram-4225, Bangladesh \\ E-mail: uachashnstu@hotmail.com \\ Telephone: +8801828948944
}

DOI: $10.31364 / \mathrm{SCIRJ} / \mathrm{v} 8.16 .2020 . P 0620781$

http://dx.doi.org/10.31364/SCIRJ/v8.i6.2020.P0620781

\begin{abstract}
The study was conducted on present status of ornamental fishes and its future prospects from January, 2018 to December, 2018 where thirteen (13) aquarium shops were found in Chattogram. Through a well-designed research framework and questionnaire thirty six (36) aquarium species were enlisted in the study among which thirty four (34) were freshwater species and two (2) of them were marine origins. Order 'Cypriniformes'(44.12\%) and family 'Cyprinidae'(38.24\%) were most popular among ornamental fish market. In our survey, Cyprinus carpio and Carassius auratus (Orenda) were most abundantly found to sell in aquarium shops. Cichlasoma Citrinellum (1200 BDT) of order 'Perciformes' was the highest while Pangasius pangasius (20 BDT) of order 'Siluiriformes' was the lowest valuable aquarium species in Chattogram. Poor quality of local species and insufficient local hatchery was marked as the major constraint in ornamental fish business. Marketing channel no. 2 was found most popular where aquarium species reach to keepers from Kataban market via traders of Chattogram. 47\% of customers in Chattogram didn't face any major problem and $50 \%$ of them were recorded to purchase ornamental species and other necessaries from traders of Chattogram. Major problems of aquarium business in Chattogram were sorted out through this study and some recommendations were made which may be useful for future enrichment of aquarium business in Chattogram.
\end{abstract}

Key Words: Present status, future prospects, ornamental fish, Chattogram, marketing channel

\section{Introduction}

Different sorts of fishes from varieties of sources contribute to the national economy of Bangladesh. But the most valuable fish are the aquarium fish or ornamental fish based on cost per unit, length and weight (Saxena, 2003; Galib and Mohsin, 2010). Generally freshwater fish farming, prawn, shrimp, crab and snail culture along with their marketing are seen across our country. But

www.scirj.org

(C) 2020, Scientific Research Journal

http://dx.doi.org/10.31364/SCIRJ/v8.i6.2020.P0620781

This publication is licensed under Creative Commons Attribution CC BY. 
now-a-days it is seen that farmers are getting interested in pearl culture, crocodile culture and ornamental fish culture and trade. Globally ornamental fish keeping is treated as an industry due to its high market demand and profitability as well as it is a hobby that has been identified as second most popular and most popular type of pet in industrialized country (Olivier K. 2001). FAO estimated that approximately 16\% of Australian, 13\% of UK and 10\% of USA households keep ornamental fish in their houses (FAO, 1998). The main suppliers of marine species are Philippine and Indonesia and they usually trade around 1450 species worldwide. The top five exporting countries are Singapore Hong Kong, USA, The Netherlands and Germany. The ornamental fish industry has been producing an average annual growth rate of $14 \%$ since 1985 (Wood, 2001). Most recently, it was estimated that 1,471 marine ornamental fish and more than 4,000 species of ornamental freshwater fish were trade globally each year (Whittington \& Chong, 2007). An estimate carried out by Marine Products Export Development Authority of India shows that there are one million fish hobby is in India. The internal trade is estimated to be about U.S.\$3.26 million and the export trade is in the vicinity of U.S.\$0.38 million. The annual growth rate of this trade is $14 \%$ (Ghosh et al., 2003). The ornamental fish business results in rapid cash production. It has turned out a preferable one because it is easy to operate and the production and handling cost is low. Ornamental fish culture was introduced in mid of 1980 at Kataban, Dhaka ( Mostafizur et al., 2009). We have so many limitations and problems. It is not easy to expand and make ornamental fish business popular overnight. But the sector is an important source of income for rural, coastal and insular communities in developing countries and is frequently a welcome provider of employment opportunities and export revenues. In spite of having availability of limited data of ornamental fish business in Bangladesh, it can be confidently said that it has already become a profitable business in almost all the big cities. This research work will highlight present status and future prospects of ornamental fishes at Chattogram region in Bangladesh.

\section{Methodology}

The study was conducted from January, 2018 to December, 2018 in Chattogram region and was focused on Chattogram City Corporation area. To gather specific information we selected seven points under our study area. Bayejid Bostami, Chandgaon, Pahartali, Panchlaish, Khulshi, Halishahar, Kotwali, Bakalia, Bandar, Patenga, Double Mooring areas of Chattogram City Corporation (red circle marked) were the focus areas of our study. Moreover, aquarium shops in Kataban area of Dhaka were brought under study for better understanding of marketing channel of aquarium business.

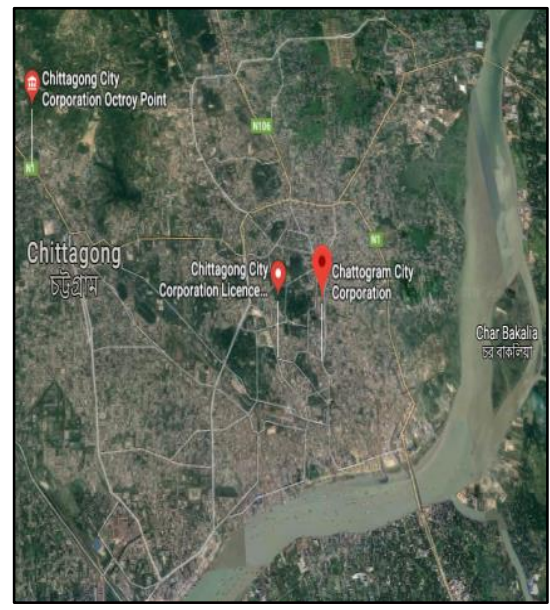

(1)

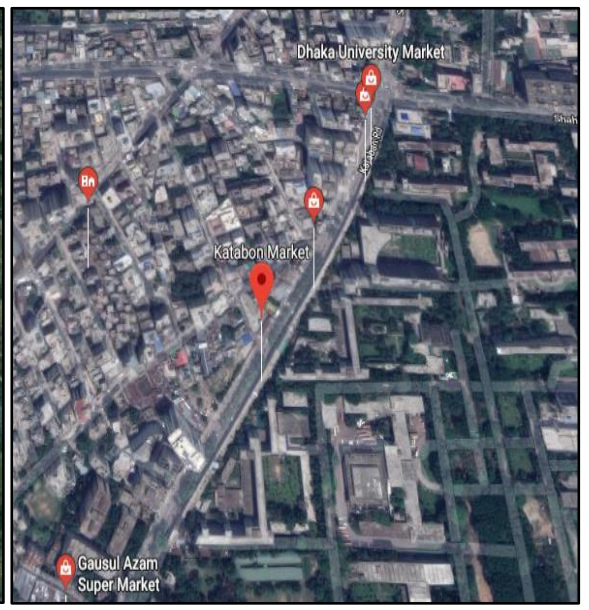

(2)

Figure 1 Study area (1) Chattogram City Corporation (2) Kataban Market, Dhaka

www.scirj.org

(C) 2020, Scientific Research Journal

http://dx.doi.org/10.31364/SCIRJ/v8.i6.2020.P0620781

This publication is licensed under Creative Commons Attribution CC BY. 
The research work was designed according to particular timeframe. The questionnaire was designed both in closed and open form based on species availability, demand, market price, market channel, major problems and suggestions. Data was collected through Questionnaire interviews, market study, photographs, key informative interviews and secondary literature. Several data collection parameters were set before data collection. All the Collected data obtained from the survey was accumulated, edited and finalized carefully and recorded.

\section{Results}

\subsection{Availability of Ornamental fish shops and aquarium species in}

Thirteen (13) aquarium shops were found operating in Chattogram city corporation area during the study period. Thirty six (36) aquarium fish species were found to sell during study period. Thirty four (34) species of them were freshwater species. Alam et al.,(2016) found Among 7shops were found in the Barisal city, 3 shops in Patuakhali town, 4 shops in Bhola town, 2 shops Pirojpur town, 1 shop in Jalokhati town and 2 shops in Borguna town. Galib et al., (2013) found only 3 aquarium shops in Jessore city.

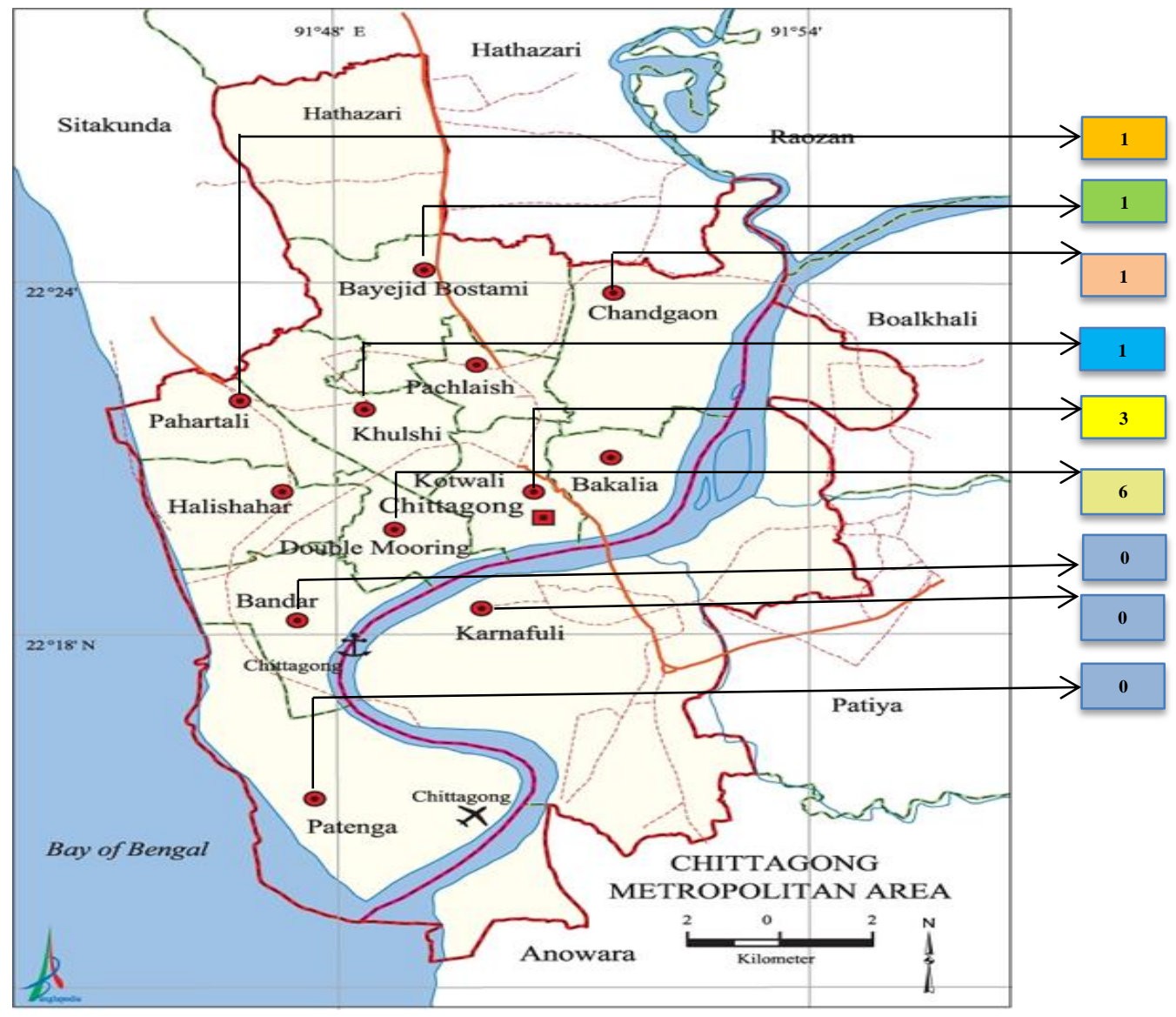

Figure 2 Location of ornamental shops in Chattogram 
Table 1 Classification of ornamental species found in Chattogram

\begin{tabular}{|c|c|c|c|}
\hline $\begin{array}{c}\text { English Name/ Common } \\
\text { name }\end{array}$ & Scientific Name & Order & Family \\
\hline 1) Tiger bulb & Puntigrus tetrazona & Cypriniformes & Cyprinidae \\
\hline 2) Comet & Carassius auratus & Cypriniformes & Cyprinidae \\
\hline 3) Tiger Shark & Sarcocheilichthys sinensis & Cypriniformes & Cyprinidae \\
\hline 4) Algae Sucker & Gyrinocheilus pustulosus & Cypriniformes & Gyrinocheilidae \\
\hline 5) Black Moor & Carassius auratus & Cypriniformes & Cyprinidae \\
\hline 6) Orenda & Carassius auratus & Cypriniformes & Cyprinidae \\
\hline 7) Zebra Danio & Danio rerio & Cypriniformes & Cyprinidae \\
\hline 8) Koi Carp & Cyprinus carpio & Cypriniformes & Cyprinidae \\
\hline 9) Amur koi carp & Cyprinus rubrofuscus & Cypriniformes & Cyprinidae \\
\hline 10) Rainbow Shark & Epalzeorhynchos frenatum & Cypriniformes & Cyprinidae \\
\hline 11) Silver Shark & Balantiocheilos melanopterus & Cypriniformes & Cyprinidae \\
\hline 12) Bala Shark & Balantiocheilos melanopterus & Cypriniformes & Cyprinidae \\
\hline 13) Ticto barb & Puntius ticto & Cypriniformes & Cyprinidae \\
\hline 14) Chinese sucker & Gyrinocheilus aymonieri & Cypriniformes & Gyrinocheilidae \\
\hline 15) Chinese Carp & Myхосурrinus asiaticus & Cypriniformes & Catostomidae \\
\hline 16) Platy & Xiphophorus maculatus & Cyprinodontiformes & Poeciliidae \\
\hline 17) Guppy & Lebistes reticulatus & Cyprinodontiformes & Poeciliidae \\
\hline 18) Molly & Poecilia sphenops & Cyprinodontiformes & Poeciliidae \\
\hline 19) Sword Tail & Xiphophorus helleri & Cyprinodontiformes & Poeciliidae \\
\hline 20) Cichlid & Aulonocara hansbaenschi & Perciformes & Cichlidae \\
\hline 21) Parrot & Cichlasoma Citrinellum & Perciformes & Cichlidae \\
\hline 22) Angel fish & Platax scalaris & Perciformes & Ephippidae \\
\hline 23) Tiger fish (Local) & Pangasius pangasius & Siluriformes & Pangasiidae \\
\hline 24) Tiger Fish (Outer) & Pangasianodon hypophthalmus & Siluriformes & Pangasiidae \\
\hline 25) Pangus & Pangasius sanitwongsei & Siluriformes & Pangasiidae \\
\hline 26) Sucker & Hypostomus plecostomus & Siluriformes & Loricariidae \\
\hline 27) Albino & Corydoras Aeneus & Siluriformes & Callichthyidae \\
\hline 28) Gourami (Blue) & Trichopodus trichopterus & Anabantiformes & Osphronemidae \\
\hline 29) Gourami(Gold) & Trichopodus trichopterus & Anabantiformes & Osphronemidae \\
\hline 30) Red Gourami & Trichogaster lalius & Anabantiformes & Osphronemidae \\
\hline 31) Pacu & Piaractus brachypomus & Characiformes & Serrasalmidae \\
\hline 32) Silver Ruji (Punti) & Metynnis argenteus & Characiformes & Serrasalmidae \\
\hline 33) Oscar & Astronotus ocellatus & Cichliformes & Cichlidae \\
\hline 34) Black Angel & Pterophyllum $s p$ & Cichliformes & Cichlidae \\
\hline $\begin{array}{l}\text { 35) Yellowtail } \\
\text { damselfish }\end{array}$ & Chrysiptera parasema & Perciformes & Pomacentridae \\
\hline $\begin{array}{l}\text { 36) Bluespotted } \\
\text { angelfish }\end{array}$ & Chaetodontoplus caeruleopunctatus & Perciformes & Pomacanthidae \\
\hline
\end{tabular}

*Number (1-34): Freshwater species

*Number (35-36): Marine water species

Alam et al., (2016) found 29 varieties in Barisal Division; 20 of these were exotic and the rest were indigenous. On the other hand, Faruk et al., (2012) found 26 ornamental fish species in Kataban Market, Dhaka in their study. Rahman et al., (2009) found 30 species during their study in Khulna District. Galib et al., (2012) also found 17 ornamental fish species in different shops in Jessore District 
while Mohsin et al., (2007) listed 17 ornamental fish species in different aquarium shops in Rajshahi. So, species availability in Chattogram is richer than any other regional area.

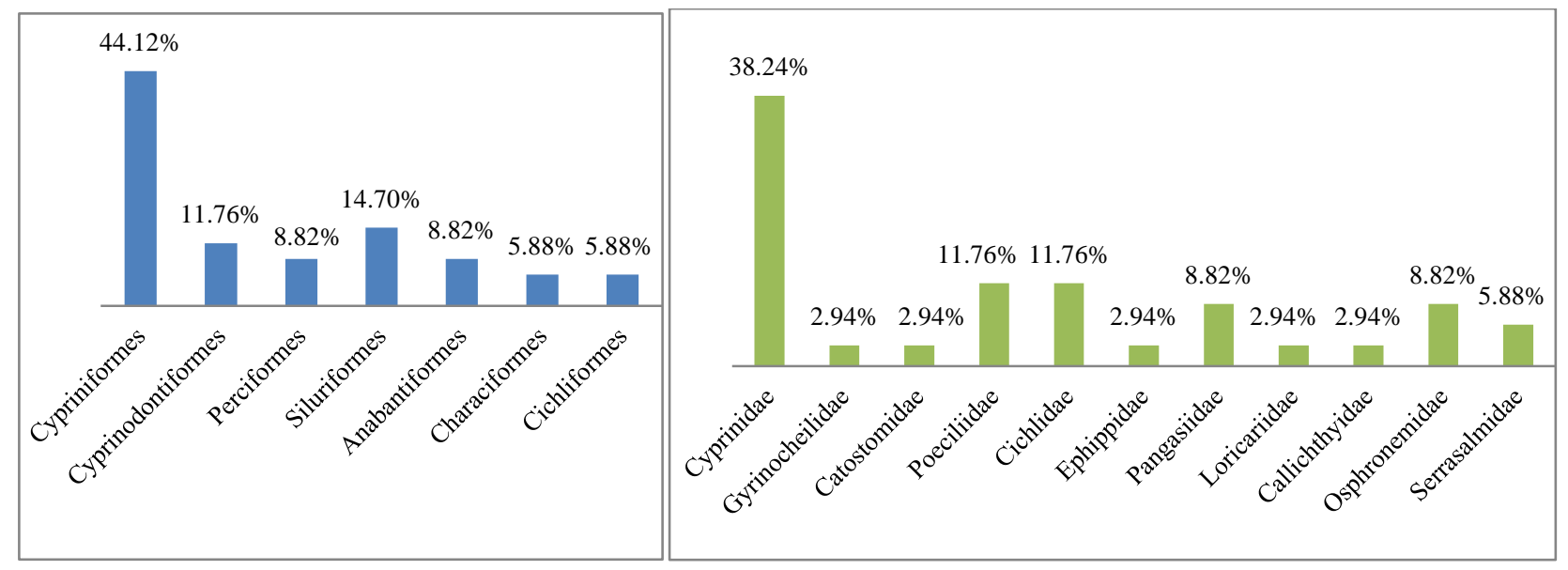

Figure 3 Availability of ornamental species according to their 'Family' and 'Order'

Alam et al., (2016) reported 'Cypriniformes' as the most dominant that covered 54\% of total ornamental fish species in Barisal Division. Galib at al., (2012) recorded the availability of order 'Cypriniformes'(52.94\%), Perciformes (23.53\%) and Siluriformes (23.53\%) in Jessore District. Panigrahi et al., (2009) conducted a survey on indigenous ornamental fish species in market of West Bengal and found family 'Cyprinidae' as the most dominant. Mandal et al.,(2007) found the major species having a large number of ornamental fishes belong to the Order 'Cypriniformes', followed by 'Siluriformes' and 'Perciformes' North-Eastern Region of India. Both 'Carassius auratus' and 'Cyprinus Carpio' was equally most dominant species in ornamental fish market in Chattogram . Faruk et al., (2012) found gold fish, comet fish, koi carp, angel fish, platy, guppy, fighter fish, parrot fish, and discuss fish were the most demandable species of ornamental fish in Kataban market. Mohsin et al., (2012) reported Gold fish found is almost 82\%, Tiger shark and Suckerfish were found in $42 \%$ and $24 \%$ aquarium orderly in aquarium market in Rajshahi. Both species availability and variety in ornammetal fish market in Chattogram are abundant than other regions of Bangladesh.

\subsection{Market price of available ornamental species in Chattogram region}

The price of Cichlasoma Citrinellum (1200 BDT) was found as the highest and the price of Pangasius pangasius (20 BDT) was found as the lowest among freshwater aquarium species in Chattogram in study period. The average price of order 'Siluiriformes' was the highest (434.17 BDT) and the aerage price of order 'Cyprinidontiformes' (29.25 BDT) was the lowest among freshwater ornamnetal fish species in Chattogram region.

www.scirj.org

(C) 2020, Scientific Research Journal

http://dx.doi.org/10.31364/SCIRJ/v8.i6.2020.P0620781

This publication is licensed under Creative Commons Attribution CC BY. 

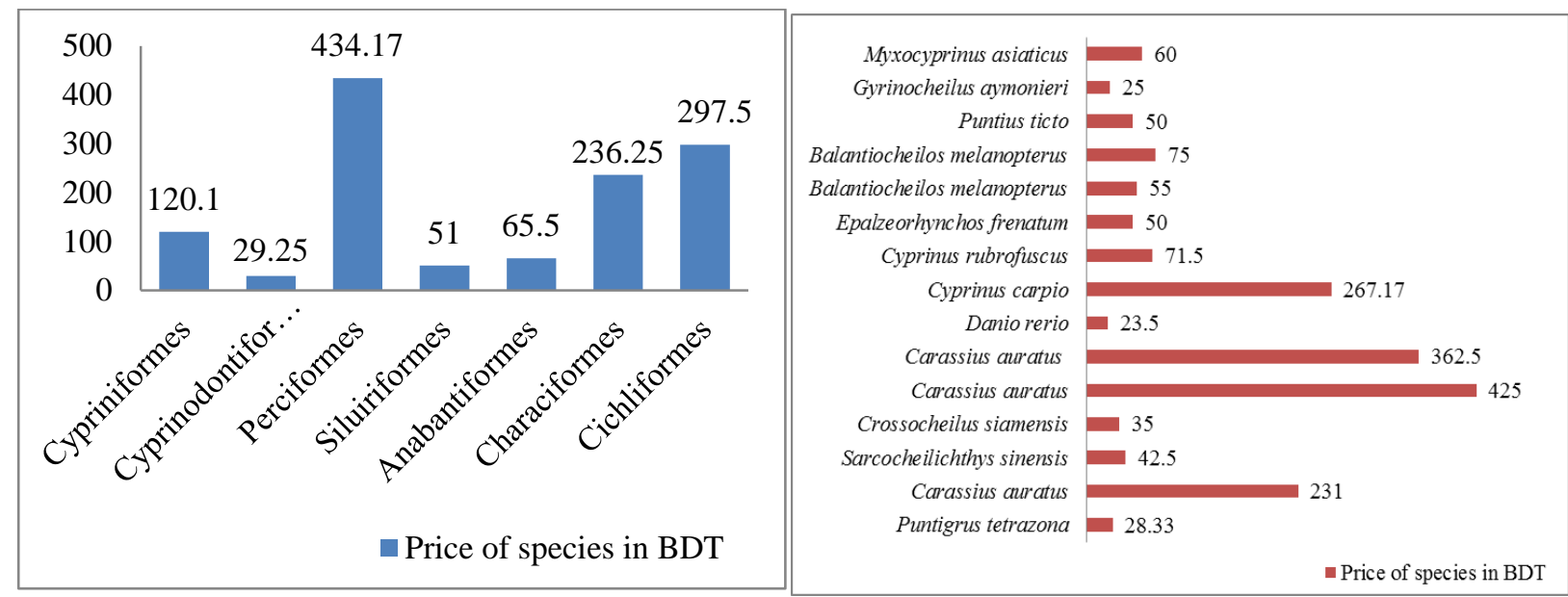

Figure 4 Price status of ornamnetal species according to their order and speceis prices of order 'Cypriniformes'

Alam et al., (2016) said that Size of fish is an important indicator for pricing of ornamental fishes. The market value was varied due to size variation. Faruk et al., (2012) noted the price range of ornamental species from BDT 60 to BDT 10,000 per pair where Black ghost had the highest price of BDT 10,000 per pair in Kataban market area. Alam et al., (2016) found that five to six inches size Oranda (Carassius auratus) was found as high valued and sold at the rate BDT 600 per pair. Indigenous fish Rosy barb was sold at least price in aquarium market in Barisal. Mohsin et al., (2007) reported the price range or ornamental species from BDT 30-300/pair in Rajshahi city. Galib et al., (2013) found the highest retail price for large silver shark (123.33 \pm 40.41 BDT/pair) followed by goldfish

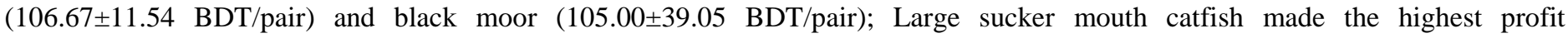
(38.33 $\pm 02.89 \mathrm{BDT} / \mathrm{pair})$ to the retails. Rahman et al., (2013) reported the price range or ornamental fishes in Khulna district from BDT 10 to 1500 where Red parrot was found as the highest valued species followed by Discus (800-1000 BDT) and Oscar (400-600 BDT).

\subsection{Marketing channels of ornamental fish species in Chattogram region:}

The study found total three (3) marketing channels operating in Chattogram. At the same time the study found total four (4) marketing channels operating in Kataban ornamental fish market, Dhaka.

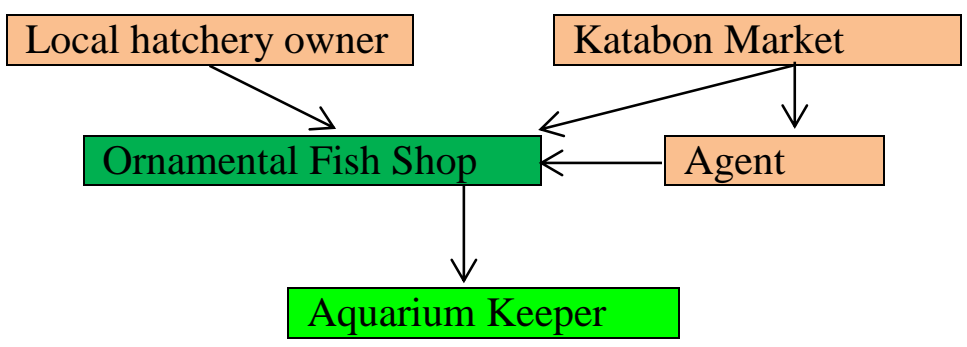

Figure 5 Marketing channel of ornamental fishes in Chattogram region

In Chattogram, most of the retailers /aquarium traders were found to purchase species directly from Kataban area. No local breeder was found during study period. Galib et al., (2013) also did not find any local breeder in Jessore town throughout their study. Faruk et al., (2012) also stated that $80 \%$ of the ornamental fish were supplied by the ornamental fish breeders to the wholesalers of Kataban area. Rahman et al., (2009) also found few local breeders in Khulna.

\section{www.scirj.org}




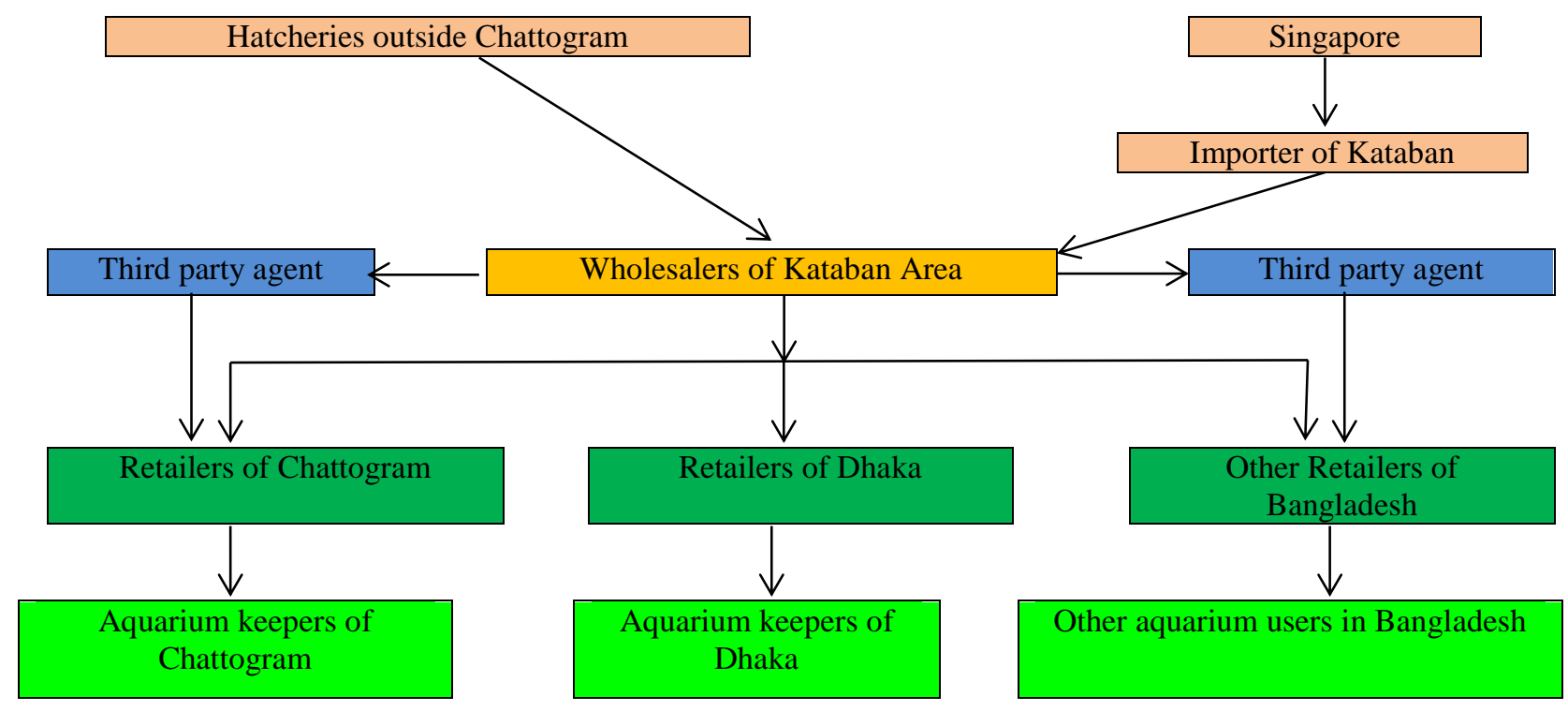

Figure 6 Marketing channel of ornamental fishes in Kataban Market, Dhaka

On the other side, four (4) marketing channel were found in Dhaka throughout study. Faruk et al., (2012) stated that throughout their study they found four (4) marketing channels in Kataban area. But they did not find the presence of third party/agent in marketing channel of aquarium business in Kataban. Ornamental fish retailers throughout the country were largely dependent a lot on Kataban aquarium fish market for exported fancy ornamental species. In Chattogram, 57\% aquarium traders were found to purchase ornamental species from only Kataban followed by both Rokomari Hatchery and Kataban (29\%) and both Kataban and other hatchery (14\%). Jayalal and Ramachandran (2012) found 287 indigenous fish species, 92 exotic fish species and 44 ornamental shrimps have been found to get exported from India. Laskar et al., (2016) conducted a study on aquarium business in Agartala, India in which about $71.43 \%$ were doing retail business and $28.57 \%$ were performing as wholesaler-cum- retailer.

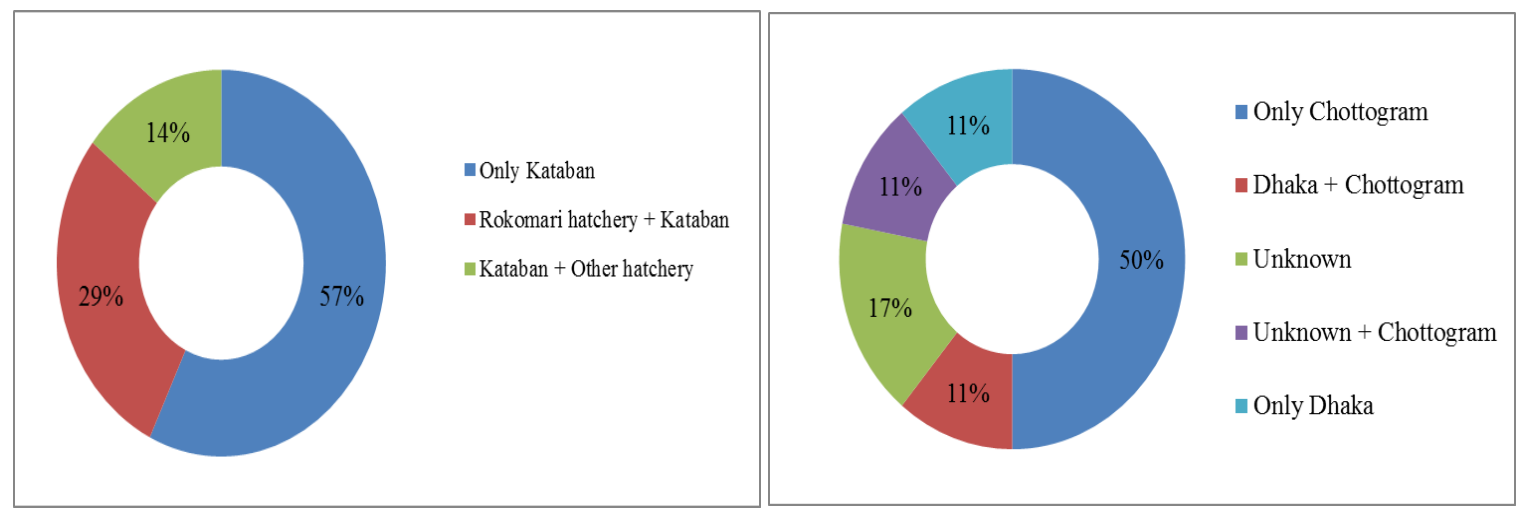

Figure7 Market sharing or ornamental fish business from traders and customers point of view

Alam et al., (2016) stated that in Barisal most of the retailers were found to purchase aquarium species directly from Kataban area but some indigenous ornamental species were caught from haor, baor, river, sundarban etc. Rahman et al., (2009) said that all the aquarium species in Khulna town were imported from international markets via Kataban market. 


\subsection{Constraints of ornamental fish business in Chattogram region}

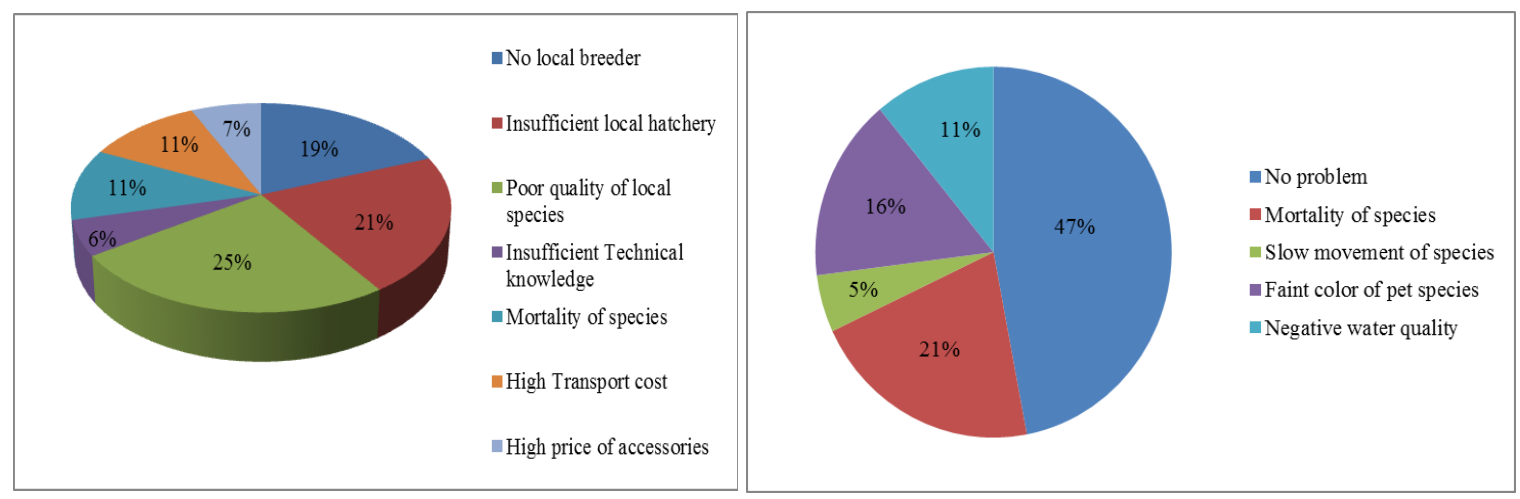

Figure 8 Major constraints of ornamental fish business from traders and customers point of view

Seven (7) major constraints were identified in aquarium business in Chattogram. According to priority marking, poor quality of species obtained the highest priority followed by insufficient local hatchery and no local breeder. $25 \%$ of total aquarium traders in Chattogram marked poor quality of species as the most major problem. About $56 \%$ of total aquarium traders in Chattogram didn't provide any type of technical support. Das et al., (2013) stated that inadequate infrastructural facilities (65.62\%), heavy investment in the initial stage $(60.12 \%)$, lack of government incentives (57.5\%) and non-availability of good quality brood fish (54.25\%) were major constraints of aquarium business in Tripura, India. In our study $47 \%$ of aquarium keepers didn't face any problem followed by mortality of species (21\%), faint color of pet species (16\%), negative water quality (11\%) and slow movement of species $(5 \%)$. Mahfuz et al., (2012) stated that larval rearing is a crucial part for extending the survivability rate of aquarium species. Smith et al., (2012) conducted a survey where sequences from their water samples were most closely related to eleven (11) bacterial species that have the potential to cause disease in aquarium fishes. Watson et al., (2002) stated that it is tough to identify particular disease in ornamental industry and also added that proper disease management is an important part of aquarium sector.

\section{Conclusion}

Ornamental fish business is a flourishing sector in modern business world. Many customers were found to purchase our indigenous ornamental species. But some constraints were recorded from retailers during study which should be solved as soon as possible for better enrichment of ornamental fish business in Chattogram. A good support from govt. may be a plus point for the expansion of this business. But considering all the data surveyed and comparing with other secondary data's we can hope to have a better future for ornamental fish business in Chattogram.

\section{References:}

Alam, M. R., Alam, J., Pattadar, S. N., Karim, R., \& Mahmud, S. (2016). Trend of ornamental fish business in Barisal division, Bangladesh. International Journal of Fisheries and Aquatic Studies, 4(3), 263-266.

Biswas, B. C., Panigrahi, A. K., Biswas, B. C., \& Panigrahi, A. K. (2014). Diversity of exotic fishes and their ecological importance in southwestern part of Bangladesh. Int. J. Innov. Res. Sci. Tech, 1, 129-131.

Chan, T. T., \& Sadovy, Y. (2000). Profile of the marine aquarium fish trade in Hong Kong. Aquarium Sciences and Conservation, 2(4), 197-213.

Faruk, M. A. R., Hasan, M. M., Anka, I. Z., \& Parvin, M. K. (2012). Trade and health issues of ornamental fishes in Bangladesh. Bangladesh Journal of Progressive Science and Technology, 10(2), 163-168. 
Galib SM, Imam MA, Rahman MA, Mohsin A, Fahad MFH. A study on aquarium fish business in Jessore district, Bangladesh. Trends in Fisheries research, 2013; 2:7.

Galib, S. M., Naser, S. A., Mohsin, A. B. M., Chaki, N., \& Fahad, M. F. H. (2013). Fish diversity of the River Choto Jamuna, Bangladesh: present status and conservation needs. International journal of biodiversity and conservation., 5(6), 389-395.

Galib, S. M., Samad, M. A., Mohsin, A. B. M., Flowra, F. A., \& Alam, M. T. (2009). Present status of fishes in the Chalan Beel-the largest beel (wetland) of Bangladesh. International Journal of Animal and Fisheries Science, 2(3), $214-218$.

Ghosh, A., Mahapatra, B. K., \& Datta, N. C. (2003). Ornamental fish farming-successful small scale aqua business in India. Aquaculture Asia, 8(3), 14-16

Kim, J. H., Hayward, C. J., Joh, S. J., \& Heo, G. J. (2002). Parasitic infections in live freshwater tropical fishes imported to Korea. Diseases of aquatic Organisms, 52(2), 169-173

Mohsin ABM, Galib SM. Handbook on exotic ornamental fishes of Bangladesh: an identifying tool. Bangladesh Fisheries Information Share Home, Rajshahi, Bangladesh. 2013, 44.

Mohsin, A. B. M., Haque, M. E., \& Islam, M. N. (2007). Status of Aquarium Fisheries of Rajshahi City. Journal of Bio-Science, 15, 169-171.

Monteiro-Neto, C., Cunha, F. E. D. A., Nottingham, M. C., Araújo, M. E., Rosa, I. L., \& Barros, G. M. L. (2003). Analysis of the marine ornamental fish trade at Ceará State, northeast Brazil. Biodiversity \& Conservation, 12(6), 1287-129

Olivier K. The ornamental fish market. FAO/Globefish Research Programme, United Nations Food and Agriculture Organization, Rome, Italy. 2001, 67.

Olivier, K. (2003). World trade in ornamental species (pp. 49-63). Ames, Iowa: Iowa State Press.

Wabnitz, C. (2003). From ocean to aquarium: the global trade in marine ornamental species (No. 17). UNEP/Earthprint.

www.scirj.org

(C) 2020, Scientific Research Journal

http://dx.doi.org/10.31364/SCIRJ/v8.i6.2020.P0620781

This publication is licensed under Creative Commons Attribution CC BY. 